\title{
Prohibition against Torture in International Law: United Nations Treaty Body
}

\author{
Aldo Shkembi \\ Lector; and PhD student in law at "European University of Tirana" \\ Cel:+355696699753/ aldo-sh86@hotmail.com
}

Andi Dura

Lawyer; Lector; and PhD student in law at "European University of Tirana" Cel: +355689019404/andi.dura@yahoo.com

\section{Doi:10.5901/ajis.2013.v2n8p61}

\begin{abstract}
Article 5 of the Universal Declaration of Human Rights 1948 reads "No one shall be subjected to torture or to cruel, inhuman or degrading treatment or punishment". This Article is widely regarded as expressing customary international law. Within the United Nations framework, torture and other cruel, inhuman or degrading treatment or punishment are explicitly prohibited under a number of international treaties, which are legally binding on those States which have ratified them. Many treaties establish Committees, known collectively as the treaty bodies, which are mandated to monitor States Parties' compliance with their obligations under the treaties. They do this by issuing General Comments or Recommendations, which provide detailed interpretation of specific aspects of the treaty. The purpose of this paper is to analyze the definition and the elements required for an act to be classified as torture or other cruel, inhuman or degrading treatment or punishment, applied within the United Nations system, by considering the General Comments and jurisprudence of the treaty bodies, in particular the Human Rights Committee (HRC), which monitors compliance with the International Covenant on Civil and Political Rights (ICCPR), and the Committee against Torture (CAT), which monitors compliance with the United Nations Convention against Torture and Other Cruel, Inhuman or Degrading Treatment or Punishment (UNCAT). The paper focuses on States Parties' obligations under the main treaties, by considering the scope of application of these obligations.
\end{abstract}

\section{Introduction}

International human rights law defines the limits of a State's power over individuals, and imposes positive obligations owed by the State to individuals. States voluntarily sign and ratify treaties that recognize and ensure the rights of every person, and submit themselves to the control of judicial or quasi-judicial organs which accept complaints from individuals. The prohibition against torture in international law is, like that against slavery or genocide, absolute. Torture is impermissible under any circumstances, including war, public emergency or terrorist threat. The prohibition is so strong and universally accepted that it is now a fundamental principle of customary international law.

This means that even States which have not ratified any of the international treaties explicitly prohibiting torture are banned from using it against anyone, anywhere. However, there is no forum at the international level to which an individual can make a complaint based solely on a violation of customary international law, so such violations often carry consequences only where there is political will among other States to hold one another responsible. The extent of all States' obligations to prevent torture is therefore largely determined by international treaties, and the bodies that interpret them.

At the international level, the United Nations' Human Rights Committee and Committee against Torture interpret State obligations under the International Covenant on Civil and Political Rights and Convention against Torture, respectively.

Finally, it should never be forgotten that, however strong the legal prohibition on torture, reality has yet to conform to the strict letter of the law. Additionally, non-judicial mechanisms are required to ensure that agents of the State do not resort to or tolerate torture, that violations are detected, and that victims receive treatment and compensation.

\section{United Nations Treaty Body}

In contrast to the regional bodies, neither the Human Rights Committee nor the Committee against Torture have found it 
necessary to make stark distinctions between torture and other prohibited ill-treatment. The 1966 International Covenant on Civil and Political Rights (ICCPR) was the first universal human rights treaty explicitly to include a prohibition of torture and other cruel, inhuman or degrading treatment, which aims to protect both the dignity and the physical and mental integrity of the individual. The two provisions of the ICCPR particularly relevant to this prohibition are Articles 7 and 10.

Article 7 ICCPR reads:

"No one shall be subjected to torture or to cruel, inhuman or degrading treatment or punishment. In particular, no one shall be subjected without his free consent to medical or scientific experimentation."

While it forbids them in absolute terms, Article 7 does not contain a definition of the prohibited acts. In its General Comment on Article 7, the HRC stated that it did not consider it necessary to draw up a list of prohibited acts or to establish sharp distinctions between torture and the other forms of ill-treatment, though such "distinctions depend on the nature, purpose and severity of the treatment applied." Therefore, in its jurisprudence, the HRC often does not specify precisely which aspect of the prohibition has been breached, but simply states that there has been a violation of Article 7 .

The HRC has indicated that the assessment of whether particular treatment constitutes a violation of Article 7 "depends on all circumstances of the case, such as the duration and manner of the treatment, its physical or mental effects as well as the sex, age and state of health of the victim." Elements such as the victim's age and mental health may therefore aggravate the effect of certain treatment so as to bring it within Article 7. However, it is not sufficient that treatment be capable of producing an adverse physical or mental effect; it must be proven that this has occurred in a specific case.

The second sentence of Article 7 ensures that the prohibition is understood to include any medical or scientific experimentation conducted without the free consent of the subject. This specific prohibition was a response to atrocities committed by doctors in Nazi concentration camps during World War II. In this regard, the Committee has stated that special protection is necessary for persons not capable of giving valid consent, in particular those deprived of their liberty, who should not be subjected to any medical or scientific experimentation that may be detrimental to their health.

Article 10 ICCPR...

Article 10(1) ICCPR states:

"All persons deprived of their liberty shall be treated with humanity and with respect for the inherent dignity of the human person." Article 10 complements, for those who have been deprived of their liberty, the prohibition of torture and ill-treatment. Not only may detainees not be subjected to treatment contrary to Article 7, but they also have a positive right to be treated with respect. This provision means that detainees may not be "subjected to any hardship or constraint other than that resulting from the deprivation of liberty; respect for the dignity of such persons must be guaranteed under the same conditions as for that of free persons."22 It therefore covers forms of treatment which would not be sufficiently severe to qualify as cruel, inhuman or degrading under Article 7. From the jurisprudence of the HRC, it seems that the Committee tends to apply Article 10(1) to general conditions of detention, reserving Article 7 for situations where an individual is subjected to specific attacks on his or her personal integrity.

To support a finding of a violation of Article 7, a detainee must show that he or she has been subjected to worse treatment than other detainees. In Pinto $v$ Trinidad and Tobago, the author complained about appalling conditions of detention, but "failed to provide details on the treatment he was subject to, other than by reference to conditions of detention that affected all inmates equally."

The HRC therefore concluded that there had been no violation of Article 7. In contrast, in Mukong v Cameroon, the fact that the author was "singled out for exceptionally harsh and degrading treatment," including being "detained incommunicado,... threatened with torture and death and intimidated, deprived of food, and kept locked in his cell for several days on end without the possibility of recreation" led the Committee to find a violation of Article 7. It may be argued that a violation of Article 7 in respect of a person deprived of liberty automatically entails a violation of Article 10(1). In Linton v Jamaica, for example, the Committee considered that "The physical abuse inflicted on the author..., the mock execution set up by prison warders and the denial of adequate medical care after the injuries sustained in the aborted escape attempt... constitute cruel and inhuman treatment within the meaning of article 7 and, therefore, also entail a violation of article 10 , paragraph 1 , of the Covenant".

In 1984, for the purposes of describing specific measures against torture, the UNCAT included a definition of torture: "any act by which severe pain or suffering, whether physical or mental, is intentionally inflicted on a person for such purposes as obtaining from him or a third person information or a confession, punishing him for an act he or a third person has committed or is suspected of having committed, or intimidating or coercing him or a third person, or for any reason based on discrimination of any kind, when such pain or suffering is inflicted by or at the instigation of or with the consent or acquiescence of a public official or other person acting in an official capacity. It does not include pain or 
suffering arising only from, inherent in or incidental to lawful sanctions".

The UNCAT also requires States to prevent "other acts of cruel, inhuman or degrading treatment or punishment which do not amount to torture..., when such acts are committed by or at the instigation of or with the consent or acquiescence of a public official or other person acting in an official capacity."

However, the UNCAT provides no definition of such acts. The Committee against Torture has itself recognized that "In practice, the definitional threshold between cruel, inhuman or degrading treatment or punishment and torture is often not clear."

One common element of the definitions of torture and other forms of ill-treatment under the UNCAT is that all must involve a public official or someone acting in an official capacity. However, for the purposes of the UNCAT, cruel, inhuman or degrading treatment may "not amount to torture" either because it does not have the same purposes as torture, or because it is not intentional, or perhaps because the pain and suffering is not "severe" within the meaning of Article 1. It is therefore instructive to analyze these aspects of the definition of torture in Article 1 in more detail.

The purposes specifically named in Article 1 do not constitute an exhaustive list; "such purposes as" indicates that other similar purposes may be included. The element joining these purposes is perhaps best understood as "some connection with the interests or policies of the State and its organs". Sufficiently severe pain or suffering inflicted by a public official purely sadistically, but for no other purpose, would therefore appear to be excluded from the definition of torture. However, it is likely that such behavior would come within the scope of the UNCAT if there was an additional element of punishment or intimidation, and acquiescence by the State.

Under both the UNCAT and the ICCPR, States parties have a duty to investigate allegations of torture or cruel, inhuman or degrading treatment.

Article 12 of the UNCAT provides:

"Each State Party shall ensure that its competent authorities proceed to a prompt and impartial investigation, wherever there is reasonable ground to believe that an act of torture has been committed in any territory under its jurisdiction."

This obligation to investigate is complemented by Article 13, which provides that individuals shall have the right to complain to the competent authorities, and that the State shall take steps to protect the complainant and witnesses against reprisal. Articles 12 and 13 also apply to acts of cruel, inhuman or degrading treatment.

Furthermore, the investigation must be effective, carried out by appropriately qualified individuals, and "seek both to determine the nature and circumstances of the alleged acts and to establish the identity of any person who might have been involved therein." At least where it is necessary to ensure the right of redress, the alleged victim must be informed of the outcome of the investigation. Article 2(1) ICCPR requires that the State ensure Covenant rights to all individuals within its territory and subject to its jurisdiction, and Article 2(3) provides that persons whose rights are violated shall have an effective remedy, with their right thereto to be determined by the competent authorities. Taken together with Article 7 , these provisions mean that "Complaints [about ill-treatment] must be investigated promptly and impartially by competent authorities."

Furthermore, the right to lodge complaints against ill-treatment must be recognized in the State's domestic law. The HRC has held that investigation should not depend on the receipt of a complaint, but should be initiated as soon as there are grounds for believing that ill-treatment has occurred. The UNCAT explicitly obliges States to enact and enforce legislation criminalizing torture, while a similar duty may also be inferred in the ICCPR.

- UNCAT....

Article 4 of the UNCAT provides:

"1. Each State Party shall ensure that all acts of torture are offences under its criminal law. The same shall apply to an attempt to commit torture and to an act by any person which constitutes complicity or participation in torture.

2. Each State Party shall make these offences punishable by appropriate penalties which take into account their grave nature." This Article is limited in its application to torture, and is not among those listed in Article 16 as applying also to other forms of ill-treatment.

The CAT now systematically asks States Parties about domestic criminal law, and has repeatedly emphasised that Article 4 requires States to "incorporate into domestic law the crime of torture and adopt a definition of torture that covers all the elements contained in article 1 of the Convention."

Where such a law has been adopted, the Committee will consider both its compatibility with the definition in Article 1 of the UNCAT and its enforcement in practice.

Article 2(2) of the ICCPR provides:

"Where not already provided for by existing legislative or other measures, each State Party to the present 
Covenant undertakes to take the necessary steps, in accordance with its constitutional processes and with the provisions of the present Covenant, to adopt such laws or other measures as may be necessary to give effect to the rights recognized in the present Covenant."

This is broader than the requirement in Article 4 of the UNCAT, both in terms of the wider range of measures to be taken and the broader scope of treatment potentially covered. For present purposes, however, as Article 7 prohibits torture and cruel, inhuman or degrading treatment or punishment, Article 2(2) specifically requires States to adopt laws or take other measures against all of these forms of ill-treatment.

The HRC clearly considers that the necessary steps to prevent violations of Article 7 will include criminalizing acts of torture and other ill-treatment, and, in its General Comment on Article 7, stated that "States Parties should indicate when presenting their reports the provisions of their criminal law which penalize torture and cruel, inhuman and degrading treatment or punishment, specifying the penalties applicable to such acts, whether committed by public officials or other persons acting on behalf of the State, or by private persons."

The Committee will consider not only the adequacy of such laws in addressing torture and other forms of illtreatment, but also their enforcement in practice. Furthermore, the HRC has stated that "[those who violate Article 7 , whether whether by encouraging, ordering, tolerating or perpetrating prohibited acts, must be held responsible."

Both the UNCAT and the ICCPR impose an obligation on States Parties to grant redress and provide adequate compensation to victims of torture or ill-treatment.

Article 14 of the UNCAT provides: "Each State Party shall ensure in its legal system that the victim of an act of torture obtains redress and has an enforceable right to fair and adequate compensation, including the means for as full rehabilitation as possible. In the event of the death of the victim as a result of an act of torture, his defendants shall be entitled to compensation."

The CAT considers that "the right to an effective remedy for a breach of the Convention underpins the entire Convention, for otherwise the protections afforded by the Convention would be rendered largely illusory." The HRC and the CAT have both generated a rich jurisprudence on the extent of State obligations related to the prohibition of torture and other cruel, inhuman or degrading treatment or punishment beyond the 'traditional' view of preventing the use of torture in interrogations. Related with the conditions of detention, both the HRC and the CAT recognise that conditions of detention may themselves constitute ill-treatment or, in extreme cases, torture. However, the wider detention system may also create conditions conducive to torture or ill-treatment, or, on the contrary, an environment in which such acts are not tolerated. Given their reduced autonomy, prisoners and other detainees are particularly vulnerable to abuse.

The ICCPR therefore includes an article explicitly requiring that detainees be treated with humanity, and the Optional Protocol to the Convention against Torture and Other Cruel, Inhuman or Degrading Treatment or Punishment aims to "establish a system of regular visits undertaken by independent international and national bodies to places where people are deprived of their liberty, in order to prevent torture and other cruel, inhuman or degrading treatment or punishment."

\section{Conclusion}

The conclusions, recommendations and decisions of the treaty bodies are not legally binding in the strictest sense; they have only advisory power. However, treaty bodies have, over time, come to make fuller use of the flexibility inherent in this relatively limited power, expanding the definitions of torture and ill-treatment, the extent of State obligations, and scope of application of the prohibition. This is also a reflection of the progress made towards entrenchment of a human rights culture in every region of the world.

The HRC, as the older of the two bodies, has been noticeably braver than the CAT in a number of the areas discussed above. The treaty bodies meet for only a few weeks per year, and therefore, while their influence is of vital importance, they can make only a limited contribution to the international jurisprudence on torture. Just as the treaty bodies inspire the regional mechanisms, much of the jurisprudence of the treaty bodies reflects standards developed by the regional mechanisms. The treaty bodies have made a particularly high number of references to decisions of the European Commission and Court of Human Rights. This is to be expected; the European regional mechanisms were the first to be established, and the system has a much higher turnover of cases than the other bodies. Thus, it has arguably developed the most detailed jurisprudence on the prohibition of torture and other ill-treatment. 


\section{References}

L. Matthew, "The Protection of Universal Human Rights: The Problem of Torture," Universal Human Rights 1 (Oct.-Dec. 1979): $25-55$.

D. Mark. "Torture and Truth", (New York: New York Review of Books, 2004), 155-6.

Burgers and Danelius, "The United Nations Convention against Torture", Martinus Nijhoff, Dordrecht, 1988, p. 119.

R. Nigel and M. Pollard, "Criminalisation of Torture: State Obligations under the United Nations Convention against Torture" [2006] E.H.R.L.R No.2, p. 115, at p. 120.

The 1966 International Covenant on Civil and Political Rights (ICCPR). Articles 7 and 10

Universal Declaration of Human Rights, G.A. res. 217A (III), U.N. Doc A/810 at 71 (1948).

Pinto v Trinidad and Tobago, HRC Communication No. 512/1992, 16 July 1996.

Mukong v Cameroon, HRC Communication No. 458/1991, 21 July 1994,

Linton v Jamaica, HRC Communication No. 255/1987, 22 October 1992.

Article 11: Article 12; Article 13; Article 14 of the UNCAT.

Article 2 of the ICCPR.

CAT, General Comment No. 2, "Implementation of article 2 by States Parties", UN Doc.

CAT/C/GC/2/CRP.1/Rev.4 (23 November 2007).

HRC, General Comment No. 31, "Nature of the General Legal Obligation Imposed on States Parties to the Covenant", UN Doc. CCPR/C/21/Rev.1/Add.13 (26 May 2004), 8. 